\title{
Infestation rates of the pedunculated barnacle Octolasmis lowei (Cirripedia: Poecilasmatidae) on the spider crab Libinia spinosa (Decapoda: Majoidea)
}

\author{
C.A.M.M. CORDEIRO ${ }^{1}$ AND T.M. COSTA $^{2}$ \\ ${ }^{1}$ UFPB, Universidade Federal da Paraíba, João Pessoa, Paraíba, Brazil, ${ }^{2}$ UNESP, Universidade Estadual de São Paulo, \\ São Vicente, Brazil
}

\begin{abstract}
The prevalence and infestation intensities of Octolasmis lowei in the branchial chambers of Libinia spinosa were evaluated according to the host's sex, size, and moult condition. Epibionts were classified as cyprid larvae, non-ovigerous or ovigerous according to their developmental stage. A median intensity of infestation of 21 epibionts/host was found (range $=1-644$; $Q_{3}=81$ ). Epibiont prevalence values (88\%) were higher on ovigerous female hosts than on males (55\%) or on non-ovigerous females (31\%). Intensity of infestation was positively correlated with host size in both sexes for non-ovigerous and ovigerous epibionts. No preference between host sex by cyprid larvae was observed, nor any correlation between cyprid abundance and host size. Cyprid larvae abundance was positively correlated with settled epibionts on both host sexes. The duration of the intermoult phase was the main factor linked to the establishment of sessile epibionts. These observations are important in relation to crabs that have a terminal moult, because these animals cannot eliminate their epibionts in future moults, thus increasing the importance of density-dependent mechanisms on epibiont establishment; in that way, prevalence of infestation alone can underestimate the real impact of infestation on the host's life cycle.
\end{abstract}

Keywords: epibiosis, marine crustaceans, interactions, cyprid larvae, spider crab, terminal moult, density dependence

Submitted 6 February 2009; accepted 7 May 2009; first published online 5 August 2009

\section{INTRDDUCTION}

The process of incrustation involves the colonization of living and non-living surfaces by sessile organisms, and when establishment occurs on a living substrate it is called epibiosis. Epibiosis frequency and intensity tend to be directly related to substrate limitations, thus this association can provide a series of advantages to the epibiont: hosts provide protection against predators (Wahl, 1989; Abelló et al., 1990); host's movements can optimize dispersal and genetic flow of the symbionts (Wahl, 1989), expanding their geographical distribution through larval dispersal (Key et al., 1996a); and, water currents generated by the movement, breathing, or feeding of the host can improve access to food and remove metabolic residues produced by the symbionts (Wahl, 1989; Key et al. 1996b).

The available space on arthropod exoskeletons and the continuous renewal of their carapaces due to moulting are two of the factors that regulate epibiont colonization patterns in communities where the occupation of new substrates is vital for survival (Levin \& Paine, 1974; Connell \& Keough, 1985). When crabs undergo ecdysis the sessile symbionts remain fixed to the exuviae (old carapace). As a consequence, these epibionts must complete their entire life cycle-settlement,

Corresponding author:

C.A.M.M. Cordeiro

Email: cammcordeiro@gmail.com metamorphosis, growth, and reproduction-during the intermoult period of their host (Abelló et al., 1990; Jeffries et al., 1992; Shields, 1992; Negreiros-Fransozo et al., 1995).

Studies of epibiont occurrence patterns can help confirm the presence or absence of terminal moult in hosts, provide data about the impact of these epibionts on host population, and help elucidate biological, behavioural and ecological characteristics of the host populations (Abelló et al., 1990; Shields, 1992; Negreiros-Fransozo et al., 1995; Messik, 1998). Nevertheless, few studies have been performed on hosts that have terminal moult (Fernández et al., 1998; Patil \& Anil, 2000; McGaw, 2006).

Previous studies indicate a predominantly positive relationship between the presence or number of epibionts and the size of the host (Jeffries et al., 1992; Voris et al., 2000; Santos \& Bueno, 2001; Lovrich et al., 2003; Yan et al., 2004), but others registered a negative correlation (Santos et al., 2006) or lack of correlation (Fernandez-Leborans \& Gabilondo, 2008). Differences on infestation levels between sexes were also explored in the literature (Abelló et al., 1990; Gili et al., 1993; McGaw, 2006; Winter \& Masunari, 2006; Fernandez-Leborans \& Gabilondo, 2008), and the results were usually related to behavioural differences.

Cirripedia is one of the most representative groups of epibionts, especially the family Poecilasmatidae, as it comprises a large number of species of pedunculated symbiotic barnacles, including the genus Octolasmis (Cólon-Urban et al., 1979; Jeffries \& Voris, 1979, 1996; Jeffries et al., 1982; 
Key et al., 1995, 1996a,b). Most of species of the genus Octolasmis are found on living substrates, and Decapod crustaceans show the highest known rates of infestation by these epibionts (Jeffries et al., 1982).

In Brazil, Octolasmis hoeki (Stebbing, 1894) was reported in the branchial chambers of Libinia spinosa $\mathrm{H}$. Milne-Edwards, 1834; while O. lowei Darwin, 1851 was found adhering to the branchial chambers of Arenaeus cribrarius (Lamarck, 1818), L. spinosa, Libinia ferreirae Brito Capello, 1871, Portunus spinimanus Latreille, 1819, Portunus spinicarpus (Stimpson, 1871), Hepatus pudibundus (Herbst, 1785), Callinectes danae Smith, 1869, Callinectes ornatus Ordway, 1863, Callinectes spp., and an unidentified majidean crab (Young, 1990; Santos et al., 2000; Santos, 2002; Santos \& Bueno, 2002; Mantelatto et al., 2003).

Bertini \& Fransozo (2004) reported the presence of L. spinosa along the Brazilian coast during the entire year at depths from $5-45 \mathrm{~m}$, as well as in great number at depths of 35-40 m. Pires (1992), Bertini \& Fransozo (2004) and Braga et al. (2005) suggest that L. spinosa is one of the most abundant species on the northern coast of São Paulo State. Despite of its abundance, only few studies were conducted in Brazil regarding the distribution (Braga et al., 2007), food habits (Barros et al., 2008) and infestation by parasites (Santos et al., 2006) and epibionts (Winter \& Masunari, 2006).

The present study evaluated the prevalence and mean intensity of infestation by Octolasmis lowei according to the sex, size, and moult stage of the host Libinia spinosa along the northern coast of São Paulo State, Brazil. The main goal of this study was to analyse how these variables behave in a terminal moult crab.

\section{MATERIALS AND METHODS}

Samples were taken at Caraguatatuba, São Sebastião, and Ubatuba bays along the northern coast of São Paulo State, Brazil (Figure 1), during the period from September 2001 to June 2002, as part of the BIOTA/FAPESP project, marine benthic invertebrates, sub-project non-consolidated infra-littoral.

Sampling was performed using transects running parallel to the coastline using a commercial fishing boat equipped with double-rigged trawl nets with $4 \mathrm{~m}$ of mouth width when expanded. Along each transect the nets were towed for 30 minutes, corresponding to a distance of about $2 \mathrm{~km}$, at depths from 5-45 m (interval $=5 \mathrm{~m}$ ).
The specimens of L. spinosa (host) captured were conserved in ice and transported to the laboratory where the following data were recorded: sex, size $(\mathrm{CW}=$ carapace width in $\mathrm{mm}$ ), moult stage (Skinner, 1962, 1985), and gonad development (Costa \& Negreiros-Fransozo, 1998). The sizes of the smallest non-infested ovigerous female $(34.2 \mathrm{~mm} \mathrm{CW})$ and the smallest non-infested male with mature gonads (38.0 $\mathrm{mm} \mathrm{CW}$ ) were used to define the juvenile phase.

In order to observe $O$. lowei in the branchial chambers, the dorsal portion of the crab was cut off and the branchial filaments removed and preserved in $70 \%$ alcohol. The infested gills were examined in posterior analyses using an optical stereomicroscope for evaluation of epibiont populations. Specimens of $O$. lowei that were found were removed and counted, and their development stages were noted (cyprid larvae, non-ovigerous, or ovigerous). Barnacles that had eggs inside the capitulum were considered ovigerous, and barnacles without eggs inside the capitulum were classified as nonovigerous. Terms like sexually mature or immature were avoided due to their relation to gonad development, which was not evaluated for $O$. lowei in this study.

Prevalence of infestation was evaluated by calculating the proportion of infested crabs (hosts) in the sample population. Intensity of infestation was considered to be the number of epibionts present on each infested host (Margolis et al., 1982; Bush et al., 1997). Due to the non-normality and heteroscedasticity of the data, the median was used as the measure of central tendency, with quartiles as a measure of dispersion.

Prevalence of infestation according to host sex and sampled area was tested using the Chi-square test. Log transformation of the data did not generate a normal distribution, so the non-parametric Kruskal-Wallis test was applied in order to evaluate variables related to host size and intensity of infestation, and Dunn's method (a posteriori) was used to identify differences among classes.

The intensity of infestation data from the different epibionts categories (cyprid larvae, non-ovigerous and ovigerous) were correlated among themselves and with host size using the Spearman's correlation index (Sokal \& Rohlf, 1995).

\section{RESULTS}

A total of 1049 specimens of L. spinosa (439 males and 610 females) were sampled, showing a $63 \%$ prevalence of infestation and median intensity of 21 epibionts/host (range: 1-644; $\left.\mathrm{Q}_{3}=81\right)$.

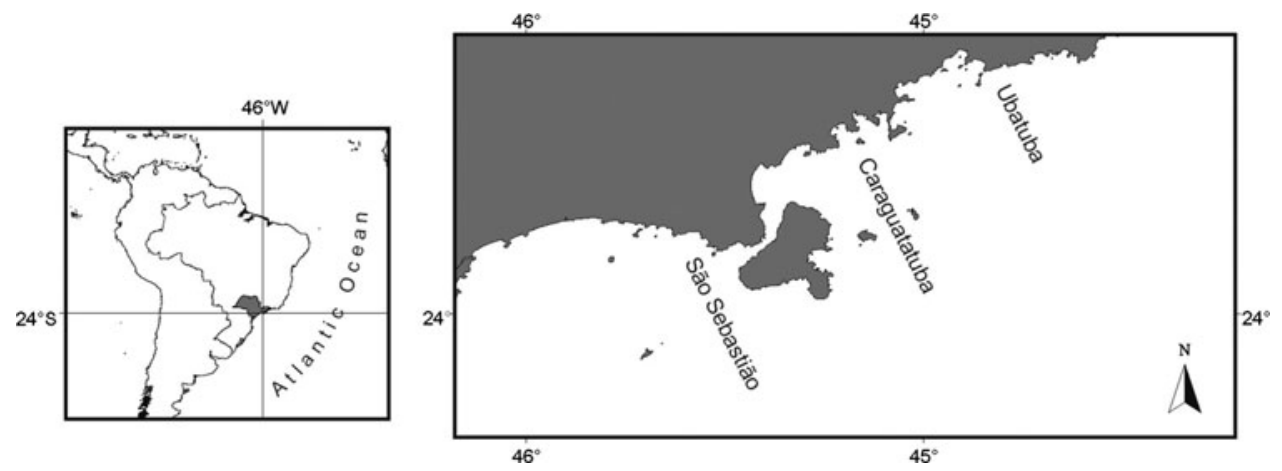

Fig. 1. Map of sampled areas on north-east coast of São Paulo, Brazil. 


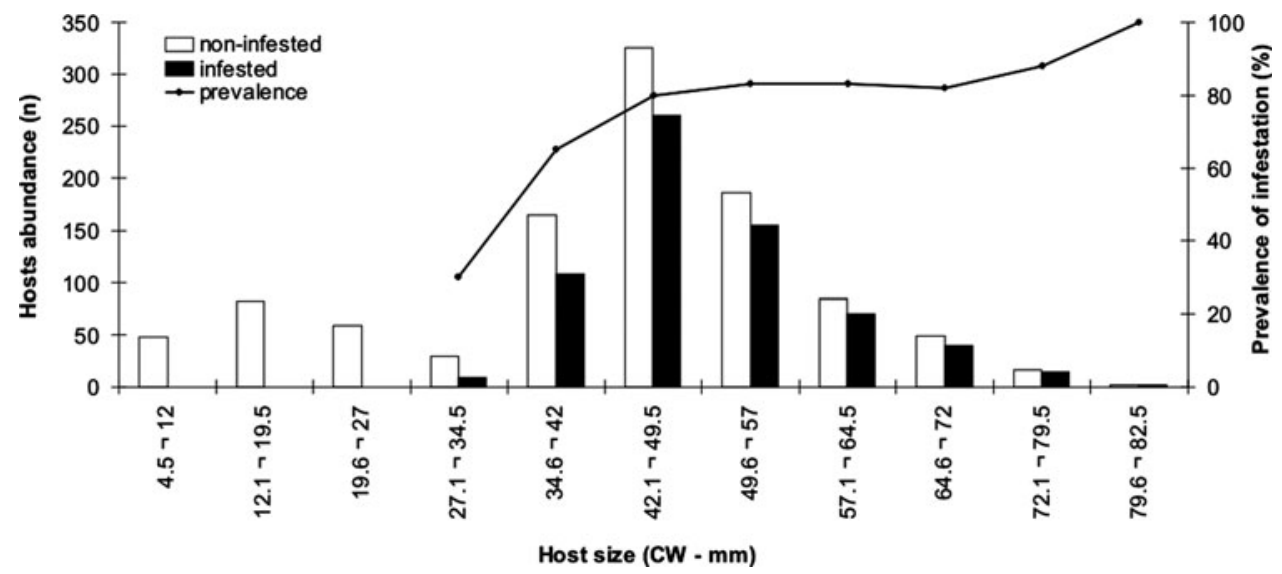

Fig. 2. Abundance and prevalence of infestation by Octolasmis lowei according to the size of the host Libinia spinosa.

The prevalence of infestation values as total are presented in Figure 2 and discriminated in Table 1 according to the sex and size of the host. The absence of infested crabs can be observed in the first three size-classes, and these correspond to juvenile population categories. The smallest infested ovigerous female of L. spinosa was $30.7 \mathrm{~mm}(\mathrm{CW})$ and the smallest infested male with developed gonads was $31.1 \mathrm{~mm}$ (CW). The infested hosts were always larger on the average than non-infested animals among individuals measuring more than $34.6 \mathrm{~mm} \mathrm{CW}(P<0.05)$ for both sexes.

There were significant differences $(P<0.05)$ between prevalence of infestation values among the demographic categories (males, non-ovigerous females and ovigerous females), with the highest values being recorded for ovigerous females, followed by the males, and then by non-ovigerous females (Table 1).

The mean sizes of the hosts according to their sex and moult stage are listed in Table 2. It can be noted that the largest number of individuals were found in the inter-moult stage and that infested crabs had larger mean sizes than noninfested crabs $(P<0.05)$. Males demonstrated larger mean sizes than females for both infested and non-infested individuals (Table 2).

A total of 30734 individuals of $O$. lowei found in the gills of L. spinosa were analysed, being: 24618 non-ovigerous, 4898 ovigerous, and 1115 cyprid larvae. As the values of median intensity of infestation (Table 3 ) did not differ between the ovigerous and non-ovigerous females categories $(P>0.05)$, these data were pooled for statistical analyses as 'females', and the pooled females were then found to differ from male values $(P<0.05)$ for this variable.

There were significant differences among the median intensities of infestation for all epibionts categories (cyprid larvae, non-ovigerous and ovigerous) for both host sexes $(P<0.05)$. The median intensity of infestation on $L$. spinosa was always higher with males than females $(P<0.05)$ for non-ovigerous and ovigerous epibionts (Table 3 ). Cyprid larvae did not show significant differences between the two host sexes $(P>0.05)$ (Table 3$)$.

As can be observed in Figure $3 \mathrm{~A} \& \mathrm{~B}$, increasing host size is followed by an increase in median intensity of infestation by ovigerous and non-ovigerous epibionts (the first three host size-classes were not included due to the absence of infested individuals), and this positive correlation can be corroborated by the results presented in Table 4. However, there was no evident relationship between host size and intensity of infestation by cyprid larvae for either host sexes (Figure ${ }_{3} \mathrm{C}$; Table 4).

Table 4 demonstrates correlation indices between host size (CW in $\mathrm{mm}$ ) and intensity of infestation among epibionts categories (cyprid larvae, non-ovigerous and ovigerous) for both host sexes. It can be seen that the correlations between epibiont categories are stronger than the correlations between host size and intensity of infestation, and that only the

Table 1. Prevalence of infestation by Octolasmis lowei on Libinia spinosa sampled along the northern coast of São Paulo State, Brazil, according to the size and sex of the host. Different letters indicate significant differences $(P>0.05)$.

\begin{tabular}{|c|c|c|c|c|c|c|}
\hline \multirow[t]{2}{*}{ Size $(\mathrm{CW}$ in $\mathrm{mm})$} & \multicolumn{2}{|c|}{ Males } & \multicolumn{2}{|c|}{ Non-ovigerous females } & \multicolumn{2}{|c|}{ Ovigerous females } \\
\hline & $\mathbf{N}$ & $\%$ & $\mathbf{N}$ & $\%$ & $\mathbf{N}$ & $\%$ \\
\hline $4 \cdot 5-12$ & 32 & o & 16 & o & 0 & o \\
\hline $12.1-19.5$ & 47 & o & 35 & o & 0 & o \\
\hline $19 \cdot 5-27$ & 33 & o & 26 & o & 0 & o \\
\hline $27.1-34.5$ & 13 & 23 & 11 & 18 & 6 & 67 \\
\hline $34.6-42$ & 25 & 52 & 24 & 46 & 116 & 72 \\
\hline $42.1-49.5$ & 60 & 67 & 26 & 81 & 240 & 83 \\
\hline $49.6-57$ & 87 & 78 & 17 & 82 & 82 & 89 \\
\hline $57.1-64.5$ & 76 & 83 & o & 0 & 8 & 88 \\
\hline $64.6-72$ & 48 & 81 & 1 & 100 & 0 & o \\
\hline $72.1-79.5$ & 16 & 88 & o & o & 0 & o \\
\hline $79.6-82.5$ & 2 & 100 & o & 0 & 0 & o \\
\hline Total & 439 & $55 \mathrm{~B}$ & 156 & $31 \mathrm{C}$ & 452 & $88 \mathrm{~A}$ \\
\hline
\end{tabular}


Table 2. Mean size (CW in $\mathrm{mm}$ ) and abundance according to moult condition and host sex (Libinia spinosa). The upper case letters beside values refer to differences between non-infested hosts, and lower case letters refer to differences between infested hosts. Different letters indicate significant differences $(P<0.05)$. Italicized values refer to the size and abundance of the ovigerous females.

\begin{tabular}{|c|c|c|c|c|c|c|c|c|}
\hline \multirow[t]{3}{*}{ Moult stage } & \multicolumn{4}{|c|}{ Non-infested } & \multicolumn{4}{|c|}{ Infested } \\
\hline & \multicolumn{2}{|c|}{ Males } & \multicolumn{2}{|c|}{ Females } & \multicolumn{2}{|c|}{ Males } & \multicolumn{2}{|c|}{ Females } \\
\hline & $\mathbf{N}$ & $\mathrm{CW} \pm \mathrm{SD}$ & $\mathbf{N}$ & $\mathrm{CW} \pm \mathrm{SD}$ & $\mathbf{N}$ & $\mathrm{CW} \pm \mathrm{SD}$ & $\mathbf{N}$ & $\mathrm{CW} \pm \mathrm{SD}$ \\
\hline Recent post-moult & 4 & $38.9 \pm 18.8$ & 3 & $37.9 \pm 2.6$ & - & - & - & - \\
\hline Post-moult & 12 & $42.9 \pm 19.6$ & 5 & $29.6 \pm 14.7$ & 1 & $37,3^{*}$ & - & - \\
\hline Intermoult & 176 & $28.7 \pm 18.8 \mathrm{~B}$ & $\begin{array}{l}99 \\
87\end{array}$ & $\begin{array}{l}22.1 \pm 11.2 \mathrm{C} \\
43.5 \pm 5.1 \mathrm{~A}\end{array}$ & $\begin{array}{l}238 \\
-\end{array}$ & $\begin{array}{l}57.3 \pm 9.7 \mathrm{a} \\
-\end{array}$ & $\begin{array}{l}49 \\
367\end{array}$ & $\begin{array}{l}45.4 \pm 7.2 \mathrm{~b} \\
45.7 \pm 4.9 \mathrm{~b}\end{array}$ \\
\hline Pre-moult & 5 & $48.6 \pm 16.5$ & - & - & 3 & $39 \pm 7 \cdot 3$ & - & - \\
\hline
\end{tabular}

*, represented by a single individual.

correlations between intensity of infestation values for cyprid larvae and host size were not observed to be significant.

Differences concerning the mean size of hosts (Table 5), percentage of juveniles $(\mathrm{CW}<34.5 \mathrm{~mm})$, prevalence (Table 5) and intensity of infestation (Table 6) were found among sampled areas. These results suggest that $L$. spinosa populations from Ubatuba and Caraguatatuba are similar, and the host population from São Sebastião is composed of larger individuals, with higher indices of infestation and predominance of females.

Regarding the distribution of L. spinosa according to depth, $76 \%$ of crabs were sampled between 20 and $35 \mathrm{~m}$. At Ubatuba, $63 \%$ of hosts were found between 15 and $20 \mathrm{~m}$. At Caraguatatuba, $60 \%$ of sampled crabs were distributed between 20 and $25 \mathrm{~m}$. And, at São Sebastião, $58 \%$ of crabs were found between 35 and $40 \mathrm{~m}$. The low number of crabs at each depth of the sampled areas did not allow statistical analysis.

The prevalence and intensity of infestation according to sex of the host followed the same pattern in all sampled areas and when analysed together. This indicates that the major influence on these indices may be associated with size and sex of the host.

\section{DISCUSSION}

The prevalence of infestation by Octolasmis lowei (63\%) on Libinia spinosa that was observed in the present study can be considered high when compared with other studies, although inferior to the $90 \%$ and $83 \%$ prevalence reported for the lobster Thenus orientalis (Lund, 1793) by Jeffries et al. $(1982,1984)$. In a study conducted by
Negreiros-Fransozo et al. (1995), prevalence of infestation in Callinectes sp. did not exceed 30\%-apparently due to constant host moulting. A similar situation was noted among the smallest individuals examined in the present study, and was also observed by Santos \& Bueno (2002) in Callinectes danae and C. ornatus, which demonstrated $22.4 \%$ and $12.1 \%$ prevalence of infestation respectively. As such, prevalence indices have been found to be low in Brazil, in spite of the large variations in prevalence of infestation in portunid crabs described by other authors: $92 \%$ in Portunus pelagicus (Gaddes \& Sumptom, 2004); 63.5\% in Charybdis callianassa (Herbst, 1789) (Walker, 2001); and 85.7\% in Charybdis feriatus (Linnaeus, 1758) (Yan et al., 2004).

As the areas sampled by Negreiros-Fransozo et al. (1995) and in the present study were very similar, the influence of environmental conditioning is attenuated and host behaviour may be the main factor influencing infestation. The low activity of $L$. spinosa would seem to facilitate the establishment of cyprid larvae, resulting in higher prevalence of infestation values than seen in more agile crabs (Connell \& Keough, 1985; Abelló et al., 1990).

In the present study, only a small portion of individuals were observed in the pre-moult phase, and these had a prevalence of infestation higher than $30 \%$, and their mean size was close to that of mature crabs. Only a few hosts found in other moult stages (post-moult and recent post-moult) had no established epibionts. Jeffries et al. (1992) observed that these moult stages are usually represented by young individuals and that epibionts are rarely found on these young crabs due to their short intermoult period-reflecting the connection between sexual maturity and the initiation of infestation. All of these arguments corroborate the observation that

Table 3. Median intensity of infestation (epi/host) according to host (Libinia spinosa) sex for all epibiont (Octolasmis lowei) categories. Upper case letters refer to differences between males and females, and lower case letters refer to differences between ovigerous and non-ovigerous females, in each column. Different letters indicate significant differences $(P<0.05)$.

\begin{tabular}{|c|c|c|c|c|c|c|c|c|c|c|c|c|}
\hline \multirow[t]{3}{*}{ Demographic category } & \multicolumn{12}{|c|}{ Epibiont categories } \\
\hline & \multicolumn{3}{|c|}{ Cyprid larvae } & \multicolumn{3}{|c|}{ Non-ovigerous } & \multicolumn{3}{|c|}{ Ovigerous } & \multicolumn{3}{|l|}{ Total } \\
\hline & Median & $\mathrm{Q}_{3}$ & Maximum & Median & $\mathbf{Q}_{3}$ & Maximum & Median & $\mathrm{Q}_{3}$ & Maximum & Median & $\mathbf{Q}_{3}$ & Maximum \\
\hline Males & $2 \mathrm{~A}$ & 4 & 102 & $38 \mathrm{~A}$ & 81 & 579 & $9 \mathrm{~A}$ & 16 & 69 & 49.5 & 101 & 644 \\
\hline Females & $2 \mathrm{~A}$ & 4 & 54 & $9 \mathrm{~B}$ & 22 & 304 & $4 \mathrm{~B}$ & 7 & 25 & 13 & 30.5 & 349 \\
\hline Non-ovigerous females & $2 \mathrm{a}$ & 5 & 10 & $8.5 \mathrm{a}$ & 21 & 90 & $4 \mathrm{a}$ & 9 & 25 & 12 & 30 & 104 \\
\hline Ovigerous females & $1 \mathrm{a}$ & 4 & 54 & $9 \mathrm{a}$ & 22 & 304 & $4 \mathrm{a}$ & 7 & 25 & 13 & 31 & 349 \\
\hline Total & 2 & 4 & 102 & 15 & 40 & 579 & 5 & 11 & 69 & 21 & 56 & 644 \\
\hline
\end{tabular}




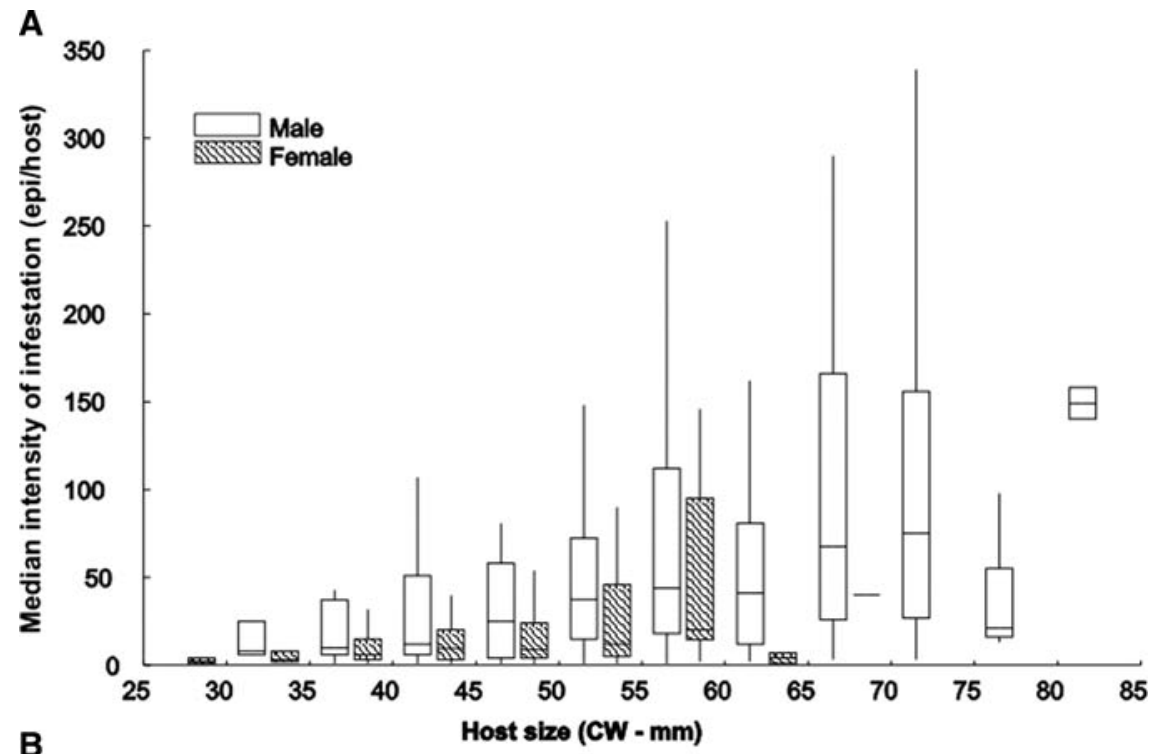

B
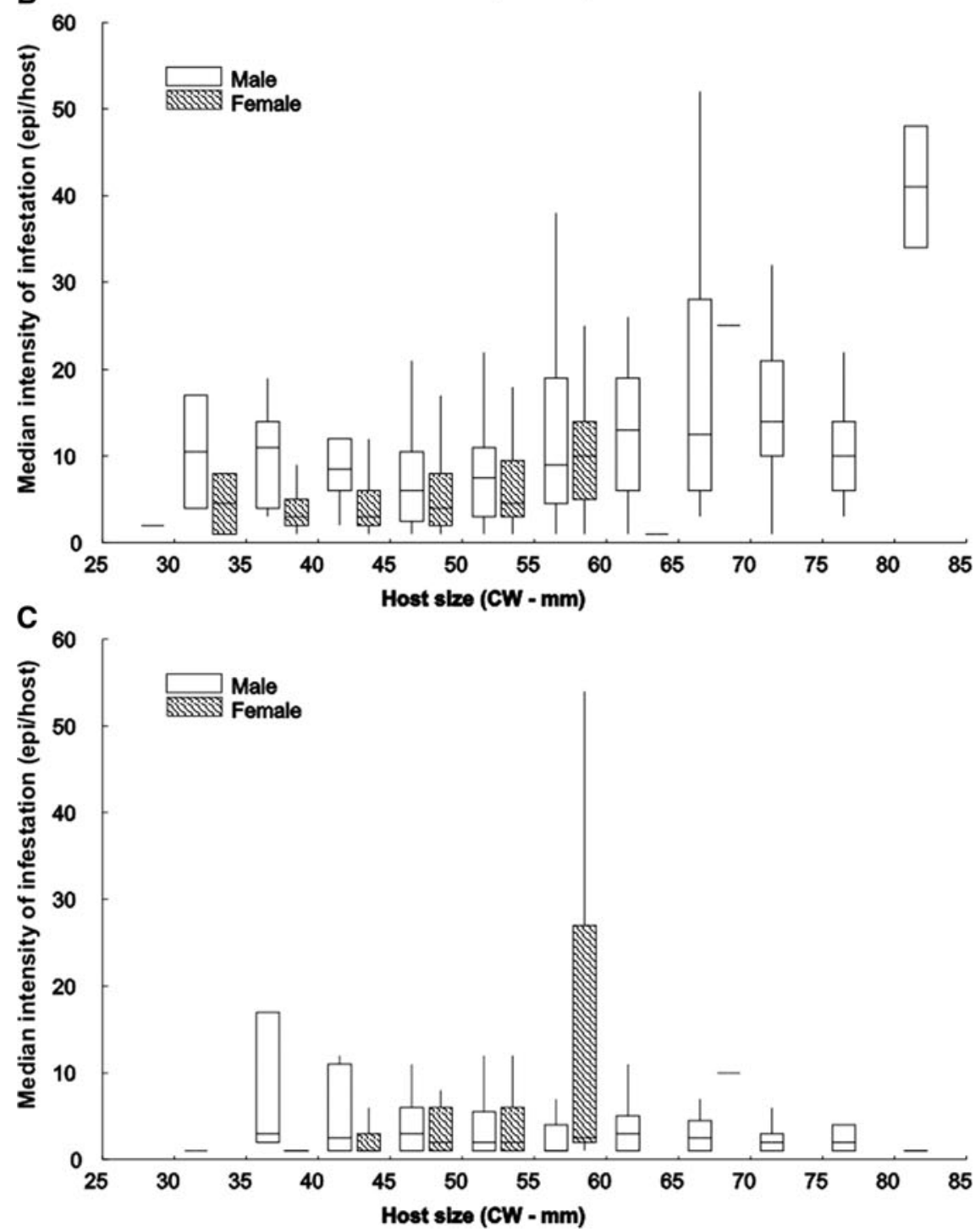

Fig. 3. Intensity of infestation by non-ovigerous (A), ovigerous (B) and cyprid larvae (C) of Octolasmis lowei in Libinia spinosa according to sex and mean size of the host. Median; Box: median $\pm 25-75 \%$; Whisker: non-outlier range. 
Table 4. Spearman's correlation index between host size (Libinia spinosa) and intensity of infestation by Octolasmis lowei, and between epibiont categories according to the host's sex.

\begin{tabular}{lllll}
\hline & & Size & Non-ovigerous & Ovigerous \\
\hline \multirow{4}{*}{ Males } & Cyprid larvae & $0.1024 \mathrm{~ns}$ & $0.4418^{*}$ & $0.3511^{*}$ \\
& Non-ovigerous & $0.3116^{*}$ & - & $0.6930^{*}$ \\
& Ovigerous & $0.3502^{*}$ & - & - \\
Females & Cyprid larvae & $0.0806 \mathrm{~ns}$ & $0.4908^{*}$ & $0.2498^{*}$ \\
& Non-ovigerous & $0.1999^{*}$ & - & $0.6170^{*}$ \\
& Ovigerous & $0.2124^{*}$ & - & - \\
\hline
\end{tabular}

*, $P<0.05$; ns, $P>0.05$.

the presence of epibionts is a good indicator of mature size in L. spinosa.

The correlation between host size and intensity of infestation and the $100 \%$ infestation rate in the largest host size-categories seen in the present study had been predicted in earlier studies for crabs which have terminal moult (Abelló et al., 1990; Jeffries et al., 1992; Voris et al., 1994). These observations indicate that the length of intermoult period is the main factor facilitating epibiont establishment; however the influence of other factors on infestation control (morphological, physiological or behavioural mechanisms) cannot be ignored.

The significant differences in prevalence of infestation in the different host demographic categories (males, nonovigerous females and ovigerous females) agree with the proposal of Shields (1992) and Wahl (2008) that behavioural, morphological, ontogenetic and physiological differences among those categories influence infestation levels. Differences between demographic categories were also examined by other authors (Abelló et al., 1990; Jeffries, et al., 1992; Shields, 1992; Gili et al., 1993; Voris \& Jeffries, 2001), and their main observation was higher infestation in ovigerous females due to their differentiated behaviour.

Similarly, as found by Walker (2001) for Charybdis callianassa, the burrowing behaviour of L. spinosa (Braga et al., 2007) could have a strong influence on infestation indices. The exposed surface area of burrowing crabs is minimized, thus reducing the surface on which cyprid larvae could first settle. As ovigerous females do not have this burrowing habit-probably to maintain the oxygenation levels of their egg masses-they remain more exposed, which facilitates the establishment of larger numbers of epibionts.

Another factor that could influence the differences in characteristics of infestation between sexes would be the host attractiveness to cyprid larvae. Many cyprid larvae are known to be able to locate highly specific substrates by following chemical cues (Foster, 1987; Pawlik, 1992; Clare, 1995). In this way, intensity of infestation by cyprid larvae would be a good indicator of attractiveness. However, the
Table 6. Median intensity of infestation by Octolasmis lowei according to host sex (Libinia spinosa) and sampled areas. Upper case letters refer to differences between areas (columns), and lower case letters refer to differences between sexes (lines). Different letters indicate significant differences $(P<0.05)$.

\begin{tabular}{llllllll}
\hline Area & \multicolumn{2}{l}{ Males } & \multicolumn{5}{l}{ Females } \\
\cline { 2 - 4 } \cline { 7 - 8 } & Median & $\mathbf{Q}_{\mathbf{3}}$ & Maximum & & Median & $\mathbf{Q}_{3}$ & Maximum \\
\hline Ubatuba & $48 \mathrm{Aa}$ & 86 & 157 & & $33 \mathrm{Ab}$ & 56 & 81 \\
Caraguatatuba & $45.5 \mathrm{Aa}$ & 76.5 & 579 & & $16 \mathrm{Bb}$ & 27 & 349 \\
São Sebastião & $59 \mathrm{Ba}$ & 120.5 & 644 & & $9 \mathrm{Cb}$ & 28 & 259 \\
\hline
\end{tabular}

values of intensity of infestation by cyprid larvae showed no differences between sexes, suggesting that there is no visible preference of the larvae with respect to the sex of the host.

Ritchie \& Höeg (1981) observed that the grooming habit of gill cleaning avoided infestation by rhizocephalan cyprid larvae (Lernaeodiscus porcellanae Müller, 1862) in a porcelanidae crab (Petrolisthes cabrilloi Glasell, 1945). Besides the probable respiratory reversion mechanism (Walker, 2001), specialized structures (scaphognatites) involved in gill cleaning could represent another important mechanism to prevent fouling in Libinia spinosa. The higher median intensity of infestation of males than of females in all size-classes, the high prevalence of infestation in ovigerous females (in spite of a generally low median intensity of infestation) and the lack of difference in the number of cyprid larvae between sexes indicate the existence of different infestation-controlling mechanisms that could increase cyprid post-settlement mortality, such as higher brachial cleaning efficiency in females.

Differences in infestation intensities by ovigerous epibionts between the two host sexes could be the consequence of a seasonal reproductive variation, density-dependent controlling mechanisms, or epibiont crossing-rates. As Octolasmis is an obligatory cross-fertilizing hermaphrodite (Jens T. Höeg, personal communication), the crossing-rate of these epibionts would be facilitated by the proximity of barnacles in high density aggregations-which is suggested by the positive correlation between non-ovigerous and ovigerous epibionts.

The presence of established conspecifics could be also an attracting factor for cyprid larvae (Pawlik, 1992; Clare, 1995), since a positive correlation was observed between intensity of infestation by cyprid larvae and previously settled epibionts (non-ovigerous and ovigerous epibionts) in the present study. Additionally, in spite of the fact that larger hosts have more epibionts, the association with size is weaker than the association between the number of sessile epibionts (non-ovigerous and ovigerous) and cyprid larvae. As L. spinosa has a terminal moult we can assume that the 'oldest' crabs will have higher infestation levels. Rotllant \&

Table 5. Total and juvenile host (Libinia spinosa) abundances, mean size (CW in $\mathrm{mm}$ ) and prevalence of infestation by Octolasmis lowei according to host sex and sampled area. Upper case letters refer to differences between areas (columns), and lower case letters refer to differences between sexes (lines). Different letters indicate significant differences $(P<0.05)$.

\begin{tabular}{|c|c|c|c|c|c|c|c|c|}
\hline \multirow[t]{2}{*}{ Area } & \multicolumn{2}{|l|}{$\mathbf{N}$} & \multicolumn{2}{|c|}{ Juvenile (\%) } & \multicolumn{2}{|l|}{ Size $(C W \pm S D)$} & \multicolumn{2}{|c|}{$\begin{array}{l}\text { Prevalence of } \\
\text { infestation }\end{array}$} \\
\hline & $\sigma^{n}$ & q & $\sigma^{\pi}$ & 운 & $\sigma^{x}$ & 우 & $\sigma^{\prime}$ & 운 \\
\hline Ubatuba & 55 & 61 & $45 \mathrm{Aa}$ & $24 \mathrm{Ab}$ & $37.8 \pm 20.7 \mathrm{Aa}$ & $39.9 \pm 12.3 \mathrm{Ab}$ & $25 \mathrm{~A}$ & $54 \mathrm{~A}$ \\
\hline Caraguatatuba & 224 & 270 & $44 \mathrm{Aa}$ & $26 \mathrm{Ab}$ & $35.8 \pm 18.6 \mathrm{Aa}$ & $38.3 \pm 13.5 \mathrm{Ab}$ & $34 \mathrm{~A}$ & $63 \mathrm{~A}$ \\
\hline São Sebastião & 160 & 279 & $<_{1} \mathrm{Ba}$ & $<_{1} \mathrm{Bb}$ & $60.3 \pm 9.3 \mathrm{Bb}$ & $44.5 \pm 5.7 \mathrm{Ba}$ & $92 \mathrm{~B}$ & $73 \mathrm{~B}$ \\
\hline
\end{tabular}


Takac (1999) observed a great variation in the final size of the crab Libinia emarginata after the terminal (puberty) moult, and this may explain the presence of smaller but older hosts. As such, these older individuals with greater intensities of infestation may be weakening the correlation between intensity of infestation and host size, possibly reflecting a positive attraction between epibionts.

The main differences in rates of infestation between regions refer to characteristics of host populations found in each area. In general, crabs from São Sebastião area had higher prevalence of infestation for being mostly females. The higher intensity of infestation may be associated with larger hosts on this area, since there is more available area for colonization by epibionts. As L. spinosa shows continuous reproduction and wide distribution in the sampled region throughout the year (Braga et al., 2007), the main influence of environmental factors would be related to the availability of $O$. lowei cyprid larvae in the water column.

In light of the fact that L. spinosa shows high prevalence and infestation intensities by $O$. lowei when compared with other sympatric hosts (Santos \& Bueno, 2001; Santos, 2002; Mantelatto et al., 2003), and as this crab is very abundant in the study area (Pires, 1992; Bertini \& Fransozo, 2004; Braga et al., 2007) it appears to have an important role in the maintenance of the adult population of $O$. lowei and, almost certainly, equal importance in maintaining the larval stock of this epibiont.

The presence of $O$. lowei in the gills of $L$. spinosa is probably a good indicator of host maturity. The main factors limiting the infestation observed in this study were: the intermoult length and size of the host; changes in rates of infestation between sexes related to the behaviour and efficiency of antifouling mechanisms. The action of these mechanisms is suggested by the difference in intensity of infestation by sessile epibionts. And, the lack of difference in intensity of infestation by $O$. lowei cyprid may be a sign of lack of preference to these epibionts between the sexes in L. spinosa.

Additional experimental studies of host and epibiont biology will be needed, however, to elucidate the details of the interaction of population parameters between epibionts and hosts, and to provide more data for new hypothesis and future studies.

\section{ACKNOWLEDGEMENTS}

The authors would like to thank FAPESP for their financial support of the BIOTA/FAPESP marine benthic invertebrate project (No. 98/07090-3), sub-project 'Non-consolidated infralittoral'; for the scholarship grants to both authors (No. 01/ 00886-1) and (No. 05/01617-5). We are also thankful to Dr Jens Höeg for valuable comments and to the two anonymous referees for helpful comments that improved this paper.

\section{REFERENCES}

Abelló P., Villanueva R. and Gili J.M. (1990) Epibiosis in deep-sea crab populations as indicator of biological and behavioural characteristics of the host. Journal of the Marine Biological Association of the United Kingdom 70, 687-695.

Barros S.P., Cobo V.J. and Fransozo A. (2008) Feeding habits of the spider crab Libinia spinosa H. Milne-Edwards, 1834 (Decapoda, Brachyura) in Ubatuba bay, São Paulo, Brazil. Brazilian Archives of Biology and Technology 51, 413-417.
Bertini G. and Fransozo A. (2004) Bathymetric distribution of brachyuran crab (Crustacea, Decapoda) communities on coastal soft bottoms off southeastern Brazil. Marine Ecology Progress Series 279, $193-200$.

Braga A.C.A., Fransozo A., Bertini G. and Fumis P.B. (2005) Composition and abundance of the crabs (Decapoda, Brachyura) off Ubatuba and Caraguatatuba, northern coast of São Paulo, Brazil. Biota Neotropica $5,1-34$.

Braga A.C.A., Fransozo A., Bertini G. and Fumis P.B. (2007) Bathymetric distribution and recruitment of the spider crab Libinia spinosa H. Milne-Edwards, 1834 (Brachyura, Majoidea) in the Ubatuba and Caraguatatuba regions, northern coast of São Paulo State, Brazil. Senckenbergiana Biologica 87, 7-16.

Bush A.O., Lafferty K.D., Lotz J.M. and Shostak A.W. (1997) Parasitology meets ecology on its own terms: Margolis et al. Revisited. Journal of Parasitology 83, 575-583.

Clare A.S. (1995) Chemical signals in barnacles: old problems, new approaches. In Schram F.R. and Höeg J.T. (eds) New frontiers in barnacle evolution. Crustacean Issues 10. Rotterdam: A.A. Balkema, pp. 49-67.

Colón-Urban R., Cheung P.J., Ruggieri G.D. and Nigrelli F. (1979) Observations on the development and maintenance of the deep sea barnacle, Octolasmis aymonini geryonophila (Pilsbry). International Journal of Invertebrate Reproduction 1, 245-252.

Connell J.H. and Keough M.J. (1985) Disturbance and patch dynamics of subtidal marine animals on hard substrata. In Pickett S.T.A. and White P.S. (eds) The ecology of natural disturbance and patch dynamics. San Diego, CA: Academic Press, pp. 135-151.

Costa T.M. and Negreiros-Fransozo M.L. (1998) The reproductive cycle of Callinectes danae Smith, 1869 (Decapoda, Portunidae) in the Ubatuba region, Brazil. Crustaceana 71, 615-627.

Fernández L., Paparar J., González-Gurriarán E. and Muíño R. (1998) Epibiosis and ornamental cover patterns of the spider crab Maja squinado on the Galician Coast, Northwestern Spain: influence of behavioral and ecological characteristics of the host. Journal of Crustacean Biology 18, 728-737.

Fernandez-Leborans G. and Gabilondo R. (2008) Invertebrate and protozoan epibionts on the velvet swimming crab Liocarcinus puber (Linnaeus, 1767) from Scotland. Acta Zoologica 89, 1-17.

Foster B.A. (1987) Barnacle ecology and adaptation. In Southward A.J. (ed.) Barnacle biology. Crustacean Issues 5. Rotterdam: A.A. Balkema, pp. 113-133.

Gaddes S.W. and Sumptom W.D. (2004) Distribution of barnacle epizoites of the crab Portunus pelagicus in Moreton Bay region, eastern Australia. Journal of Marine and Freshwater Research 55, 241-248.

Gili J.M., Abelló P. and Villanueva R. (1993) Epibionts and intermoult duration in the crab Bathynectes piperitus. Marine Ecology Progress Series 98, 107-113.

Jeffries W.B. and Voris H.K. (1979) Observation on the relationship between Octolasmis grayii (Darwin, 1851) (Cirripedia: Thoracica) and certain marine snakes (Hydrophiidae). Crustaceana 37, 123-132.

Jeffries W.B. and Voris H.K. (1996) A subject-indexed bibliography of the symbiotic barnacles of the genus Octolasmis Gray, 1825 (Crustacea: Cirripedia: Poecilasmatidae). Raffles Bulletin of Zoology $44,575-592$.

Jeffries W.B., Voris H.K. and Yang C.M. (1982) Diversity and distribution of the pedunculate barnacle Octolasmis in the seas adjacent to Singapore. Journal of Crustacean Biology 2, 562-569.

Jeffries W.B., Voris H.K. and Yang C.M. (1984) Diversity and distribution of the pedunculate barnacle Octolasmis Gray, 1825, epizoic on the scyllarid lobster, Thenus orientalis (Lund, 1793). Crustaceana $46,300-308$. 
Jeffries W.B., Voris H.K. and Poovachiranon S. (1992) Age of the mangrove crab Scylla serrata at colonization by stalked barnacles of the genus Octolasmis. Biological Bulletin. Marine Biological Laboratory, Woods Hole 182, $188-194$.

Key M.M. Jr., Jeffries W.B. and Voris H.K. (1995) Epizoic bryozoans, sea snakes and other nektonic substrates. Bulletin of Marine Science 56 $462-474$.

Key M.M. Jr., Jeffries W.B., Voris H.K. and Yang C.M. (1996a) Epizoic bryozoan and mobile ephemeral host substrata. In Gordon D.P., Smith A.M. and Grant-Mackie J.A. (eds) Proceedings of the 1oth Internationa Bryozoology Conference, Wellington, New Zealand. Wellington: National Institute of Water and Atmospheric Research Ltd., pp. 157-165.

Key M.M. Jr., Jeffries W.B., Voris H.K. and Yang C.M. (1996b) Epizoic bryozoans, horseshoe crabs, and other mobile benthic substrates. Bulletin of Marine Science 58, 368-384.

Levin S.A. and Paine R.T. (1974) Disturbance, patch formation and community structure. Proceedings of the National Academy of Sciences of the USA 71, 2744-2747.

Lovrich G.A., Calcagno J.A. and Smith B.D. (2003) The barnacle Notobalanus flosculus as an indicator of the intermolt period of the male lithodid crab Paralomis granulose. Marine Biology 143, 143-156.

Mantelatto F.L., O'Brien J.J. and Biagi R. (2003) Parasites and symbionts of crabs from Ubatuba bay, São Paulo State, Brazil Comparative Parasitology 70, 211-214.

Margolis L., Esch G.W., Holmes J.C., Kuris A.M. and Shad G.A. (1982) The use of ecological terms in parasitology (report of an ad hoc committee of the American Society of Parasitology). Journal of Parasitology $66,131-133$.

McGaw I.J. (2006) Epibionts of sympatric species of Cancer crabs in Barkley Sound, British Columbia. Journal of Crustacean Biology 26, $85-93$.

Messik G.A. (1998) Diseases, parasites, and symbionts of blue crabs (Callinectes sapidus) dredged from Chesapeake Bay. Journal of Crustacean Biology 18, 533-548.

Negreiros-Fransozo M.L., Costa T.M. and Fransozo A. (1995) Epibiosis and molting in two species of Callinectes (Decapoda: Portunidae) from Brazil. Revista de Biología Tropical 43, 257-264.

Patil J.S. and Anil A.C. (2000) Epibiotic community of the horseshoe crab Tachypleus gigas. Marine Biology 136, 699-713.

Pawlik J.R. (1992) Chemical ecology of the settlement of benthic marine invertebrates. Oceanography and Marine Biology: an Annual Review 30, 273-335.

Pires A.M.S. (1992) Structure and dynamics of benthic megafauna on the continental shelf offshore of Ubatuba, Southeastern Brazil. Marine Ecology Progress Series 86, 63-76.

Ritchie L.E. and Höeg J.T. (1981) The life history of Lernaeodiscus por cellanae (Cirripedia: Rhizocephala) and co-evolution with its porcellanid host. Journal of Crustacean Biology 1, 334-347.

Rotllant G. and Takac P. (1999) Ecdysones in the maturational moult of juvenile females of the spider crab, Libinia emarginata Leach, 1845 (Decapoda, Majidae). Crustaceana 72, 221-231.

Santos C. and Bueno S.L. (2001) Prevalence and mean intensity of infestation by Carcinonemertes carcinophila iminuta (Nemertea: Carcinonemertidae) in the gills of Callinectes danae and Callinectes ornatus (Decapoda: Portunidae) from São Sebastião, Brazil. Hydrobiologia 456, 65-71.

Santos C. and Bueno S.L. (2002) Infestation by Octolasmis lowei (Cirripedia: Poecilasmatidae) in Callinectes danae and Callinectes ornatus (Decapoda: Portunidae) from São Sebastião, Brazil. Journal of Crustacean Biology 22, 241-248.
Santos C., Bueno S.L. and Shimizu R.M. (2000) Distribution of Octolasmis lowei and Carcinonemertes carcinophila in the branchial chamber of Callinectes danae and Callinectes ornatus. Nauplius 8, 25-34.

Santos S. (2002) Symbiosis between Portunus spinimanus Latreille, 1819 (Decapoda, Portunidae) and Octolasmis lowei (Darwin, 1852) (Thoracica, Poecilasmatidae) from Ubatuba, São Paulo, Brazil. In Escobar-Briones E. and Alvarez F. (eds) Modern approaches to the study of Crustacea. New York: Kluwer Academic: Plenum Publishers, pp. 205-209.

Santos C., Bueno C.L.S. and Norenburg J.L. (2006) Infestation by Carcinonemertes divae (Nemertea: Carcinonemertidae) in Libinia spinosa (Decapoda: Pisidae) from São Sebastião Island, SP, Brazil. Journal of Natural History 40, 999-1005.

Shields J.D. (1992) Parasites and symbionts of the crab Portunus pelagicus from Moreton Bay, eastern Australia. Journal of Crustacean Biology 12 , 94-100.

Skinner D.M. (1962) The structure and metabolism of a crustacean integumentary tissue during a molt cycle. Biological Bulletin. Marine Biological Laboratory, Woods Hole 123, 635-647.

Skinner D.M. (1985) Interacting factors in the control of the crustacean molt cycle. American Zoologist 25, 275-284.

Sokal R.R. and Rohlf F.J. (1995) Biometry. The principles and practice of statistics in biological research. 3 rd edition. New York: W.H. Freeman and Company.

Voris H.K. and Jeffries W.B. (2001) Distribution and size of a stalked barnacle (Octolasmis mülleri) on the blue crab, Callinectes sapidus. Bulletin of Marine Science 68, 181-190.

Voris H.K., Jeffries W.B. and Poovachiranon S. (1994) Patterns of distributions of two barnacle species on the mangrove crab Scylla serrata. Biological Bulletin. Marine Biological Laboratory, Woods Hole 187, $346-354$.

Voris H.K., Jeffries W.B. and Poovachiranon S. (2000) Size and location relationships of stalked barnacles of the genus Octolasmis on the mangrove crab Scylla serrata. Journal of Crustacean Biology 20, 483-494.

Wahl M. (1989) Marine epibiosis. I. Fouling and antifouling: some basic aspects. Marine Ecology Progress Series 58, 175-189.

Wahl M. (2008) Ecological lever and interface ecology: epibiosis modulates the interactions between host and environment. Biofouling 24 , $427-438$.

Walker G. (2001) Some observations on the epizoic barnacle Octolasmis angulata within the branchial chambers of an Australian swimming crab. Journal of Crustacean Biology 21, 450-455.

Winter V.C. and Masunari S. (2006) Macroepizoísmo em Libinia ferreirae (Crustacea, Brachyura, Majidae). Iheringia: Série Zoologia 96, 135-140.

Yan Y., Huang L. and Miao S. (2004) Occurrence of the epizoic barnacle Octolasmis angulata on the crab Charybdis feriatus from Daya Bay, China. Journal of the Marine Biological Association of the United Kingdom 48, 619-620.

and

Young P.S. (1990) Lepadomorph cirripeds from the Brazilian coast. IFamilies Lepadidae, Poecilasmatidae and Heteralepadidae. Bulletin of Marine Science 47, 641-655.

\section{Correspondence should be addressed to:} C.A.M.M. Cordeiro DSE, CCEN, UFPB, Cidade Universitária s/n, João Pessoa, Paraíba, Brazil, CEP: 58051-9oo email: cammcordeiro@gmail.com 